\title{
Motivations of the Participants Who Post a Message in an Online Health Forum : A Qualitative and Quantitative Descriptive Study of the French Health Forum Doctissimo
}

\author{
Ambre-Laure Benazeth \\ Université de Bordeaux \\ Valentin Montané \\ Université de Bordeaux \\ Christophe Adam \\ Université de Bordeaux \\ Christèle Blanc-Bisson \\ Université de Bordeaux \\ Palina Dzeraviashka \\ Université de Bordeaux \\ Yves-Marie Vincent ( $\nabla$ vincent.yvesmarie@gmail.com ) \\ Université de Bordeaux
}

\section{Research Article}

Keywords: Online Health Forums, Patients' motivations, Patient's expectations

Posted Date: January 28th, 2022

DOI: https://doi.org/10.21203/rs.3.rs-1098968/v1

License: (c) (i) This work is licensed under a Creative Commons Attribution 4.0 International License.

Read Full License 


\section{Abstract}

Background : For over 20 years and despite the development of new social networks, health forums have remained a privileged place for patients to exchange around health issues. This study researches the participants' motivations to post a message in an online French Health Forum (called 'Doctissimo').

Method : Between 1st January 2017 and 31st December 2019, the first posts were recorded on the 'Doctissimo' health forum, in their initial format by a crawler. The transcripts were imported in the qualitative analysis software Nvivo. Two researchers codified the data until a theoretical saturation was obtained.

Results : Four categories of motivations were identified : 1) 'Requesting' allows the exchange of mainly medical information, or a feedback on experiences with the disease : $44.81 \%, 1722$ codes ; 2 ) 'Worrying, need for reassurance' : $27.74 \%, 1066$ codes; 3 ) 'Self-expressing' mainly enables catharsis leading to emotional liberation : $19.88 \%, 764$ codes; 4 ) Community spirit is a central element to create an emotional support group : 7.57\%, 291 codes. The relationship and the obstacles to a medical consultation are described. When mentioned, the relationship with a healthcare professional is generally marked by doubts, confusion, or a lack of information.

Conclusion : Patients log in to confront a community, they feel free and legitimate. Resorting to the information offered by the Internet is a way of reassuring themselves or of being confirmed in their own hypothesis/ provided by a health professional. Patients are looking for an immediate response.

\section{Background}

The General Practitioner (GP) is the basis of the healthcare system in France. ${ }^{1} \mathrm{He}$ is himself a powerful therapeutic agent. ${ }^{2}$ The social and psychological elements of the relationship with the health professional are of great importance to the patient. ${ }^{3}$

In the studies carried out in primary care, the majority of patients expressed the wish that their GP understands their problem, is a skilled listener, is empathetic and could provide clear explanations. ${ }^{3-6}$

Nowadays, the practitioner is no longer the only source of information, given the increased development of means of communication and exchange. Resources used in the population to answer medical questions outside of consultations are of interest to GPs.

The Internet takes up more and more space in health, medical information through this means is continuously accessible, since most people have permanent access to the Internet through their phone. ${ }^{7}$ The quality of this information is heterogeneous and difficult to assess. ${ }^{8}$

Online discussion forums are privileged places of expression for users. The conversation is instantaneous, asynchronous, directly transcribed, the anonymity can be guaranteed, the speech is 
liberated. ${ }^{9-11}$

In the health care domain, these online forums have a significant audience. In January 2020, 13,903,000 users per month visited the health forum 'Doctissimo', and 939,000 per day. ${ }^{12}$

The forums allow access to medical information but also to experiences of living with the disease, tips. Emotions are therefore mixed with medical details. ${ }^{11,13}$ Users go first to a forum that focuses on a health problem similar to their own. ${ }^{14}$ The expressed feelings are often polarized (positive and negative) $)^{13}$;

however, this dichotomy is not sufficient for the analysis of a forum. ${ }^{15}$

As a health professional, the place of these social health networks is undeniable in our practice. In order to understand the expectations of patients, we decided to study the social networks related to health and in particular the Health Forum 'Doctissimo'. Our main objective is to describe the motivations for posting a first message, starting a discussion topic, in order to identify what these patients find in these online health forums rather than during a visit to their doctor, and in which proportion.

\section{Methods}

\section{Study design, Data collection, Sampling}

This study is a qualitative and quantitative, non-directive, retrospective descriptive study.

The data of this study are represented by the first messages of a thread, posted on the 'Forum de santé Doctissimo'. These verbatims are kept in their original form, without changing the spelling and collected in a systematic computerized way using a crawler. For the purpose of this article, the verbatims are translated into corrected English.

These verbatims are taken by successive categories (created by the Doctissimo site), in the order of arrival (last commented message).

\section{Ethical consideration}

The information in this forum is public, freely available on the Internet, therefore agreement is not required.

\section{Data Analysis}

Message content is coded using 'NVivo' software by two separate researchers. The verbatims are analyzed as they are received, using the grounded theory method. ${ }^{16,17}$

The posts being numerous it allowed a quantitative analysis by means of the 'Excel software, from obtained qualitative results. 


\section{Results}

Between January 1, 2017 and December 31, 2019, 10,000 posts were approximately identified. The data saturation occurred after the analysis of 1584 posts ( 7 posts were removed from the analysis because of their uninterpretable character or because they were messages from the moderator).

\section{Principal motivations}

The main categories represented by the coding frequency, respond to the principal objective. (Fig 1, Table 1.) The key motivations are: 'requesting', 'worrying, need for reassurance', 'self-expressing', a sense of community.

Table 1. Users motivations on the 'Doctissimo' Health Forum

\section{Requesting (Fig 2)}

Most users seem to go to the 'Doctissimo' health discussion forum to ask a question. The 'request' section is the one that is coded most frequently. It includes heterogeneous sub-categories. Among these questions, those related to a purely medical subject come up most. "Isn't it possible to detect a possible Alzheimer when having a scan?", "Is it the trigger finger? [...] Is there anything I can do besides rest?», "I think I'm running out of benzodiazepines [...] so can you tell me if I can compensate with SOLIAN or THERALENE or ABILIFY.»

The feedback request is also at the heart of the users' motivations. "I think I have described my symptoms the best I can. Although I do not expect a medical diagnosis from you, you have an experience that no doctor has. »

\section{Worrying, Need for reassurance (Fig 3)}

Looking for reassurance comes second, with users expressing their concerns on the health forum. These apprehensions are most often related to a deviation from the norm, in particular symptoms that alarm the participants (pain, physical or functional signs) : «I am reaching out for a problem that worries me a lot [...] For the past month I have had a slight pain in my forehead.», "[...] What do you think of the kind of red "patch" or "lump" I have in my throat? [...] I noticed it 2-3 days ago and it has been worrying me ever since.», "here I am, stumbling over my words, mixing them up. [...] this really worries me. ».

The manifestation of anticipatory anxiety is also widely represented, for example, the fear of having a severe illness : "It's stupid but I'm afraid of having bone cancer or polyarthritis, something like that», or fear of surgery : "I'm going to have surgery on my diverticula and I'm a little stressed... »

3. Self-expressing (Fig 4) 


\begin{tabular}{|c|c|c|c|c|c|}
\hline Categories & Subcategories & - & $\begin{array}{l}\text { Number } \\
\text { of } \\
\text { codes }\end{array}$ & $\begin{array}{l}\text { Percentage } \\
\text { per } \\
\text { category. }\end{array}$ & $\begin{array}{l}\text { Overall } \\
\text { percentage }\end{array}$ \\
\hline $\begin{array}{l}\text { REQUESTING } \\
1722 \text { codes }\end{array}$ & \multicolumn{2}{|l|}{$\begin{array}{l}\text { Requesting medical } \\
\text { information (technical } \\
\text { medical } \\
\text { questions/guidance, } \\
\text { advice/diagnosis/advice } \\
\text { on treatment) }\end{array}$} & 1111 & $64.52 \%$ & $28.91 \%$ \\
\hline & $\begin{array}{l}\text { Asking for feedback, } \\
\text { looking for a similar } \\
\text { experience }\end{array}$ & & 453 & $26.31 \%$ & $11.79 \%$ \\
\hline & $\begin{array}{l}\text { Asking for non-medical } \\
\text { advice, non-medical } \\
\text { information }\end{array}$ & & 133 & $7.72 \%$ & $3.46 \%$ \\
\hline & $\begin{array}{l}\text { Asking for a } \\
\text { deontological - moral - } \\
\text { medico-legal - ethical } \\
\text { advice }\end{array}$ & & 25 & $1.45 \%$ & $0.65 \%$ \\
\hline $\begin{array}{l}\text { WORRYING } \\
\text { NEED FOR } \\
\text { REASURANCE }\end{array}$ & $\begin{array}{l}\text { Deviation from a } \\
\text { standard }\end{array}$ & $\begin{array}{l}\text { Concerns } \\
\text { about } \\
\text { symptoms }\end{array}$ & 386 & $36.21 \%$ & $10.04 \%$ \\
\hline \multirow[t]{5}{*}{1066 codes } & & $\begin{array}{l}\text { Concerns } \\
\text { about a } \\
\text { biological sign, } \\
\text { test results }\end{array}$ & 67 & $6.29 \%$ & $1.74 \%$ \\
\hline & & $\begin{array}{l}\text { Concerns } \\
\text { about a feeling } \\
\text { of behavioral } \\
\text { or physical } \\
\text { abnormality }\end{array}$ & 47 & $4.41 \%$ & $1.22 \%$ \\
\hline & & $\begin{array}{l}\text { Concerns } \\
\text { about a feeling } \\
\text { of loss of } \\
\text { control }\end{array}$ & 22 & $2.06 \%$ & $0.57 \%$ \\
\hline & $\begin{array}{l}\text { Anticipation, Event } \\
\text { preparation, Risk } \\
\text { assessment }\end{array}$ & $\begin{array}{l}\text { Concerns } \\
\text { related to an } \\
\text { evolutionary } \\
\text { process } \\
\text { (evolution of a } \\
\text { disease, } \\
\text { healing } \\
\text { process, after- } \\
\text { effects, } \\
\text { relapse) }\end{array}$ & 197 & $18.48 \%$ & $5.13 \%$ \\
\hline & & Concerns & 103 & $9.66 \%$ & $2.68 \%$ \\
\hline
\end{tabular}




\begin{tabular}{|c|c|c|c|c|c|}
\hline & & $\begin{array}{l}\text { about having a } \\
\text { severe illness }\end{array}$ & & & \\
\hline & & $\begin{array}{l}\text { Concerns } \\
\text { related to a } \\
\text { surgical } \\
\text { intervention, a } \\
\text { future medical } \\
\text { contact, a need } \\
\text { for } \\
\text { hospitalization. }\end{array}$ & 59 & $5.53 \%$ & $1.54 \%$ \\
\hline & & $\begin{array}{l}\text { Concerns } \\
\text { about a life } \\
\text { choice, life } \\
\text { event }\end{array}$ & 39 & $3.66 \%$ & $1.01 \%$ \\
\hline & $\begin{array}{l}\text { Concerns about taking a } \\
\text { treatment or substance } \\
\text { and its side effects }\end{array}$ & & 76 & $7.13 \%$ & $1.98 \%$ \\
\hline & $\begin{array}{l}\text { Concerns related to } \\
\text { diagnostic or therapeutic } \\
\text { errancy }\end{array}$ & & 70 & $6.57 \%$ & $1.82 \%$ \\
\hline $\begin{array}{l}\text { SELF- } \\
\text { EXPRESSING }\end{array}$ & $\begin{array}{l}\text { A negative feeling, } \\
\text { catharsis }\end{array}$ & & 354 & $46.34 \%$ & $9.21 \%$ \\
\hline 764 codes & $\begin{array}{l}\text { Telling one' s story, } \\
\text { testifying }\end{array}$ & & 281 & $36.78 \%$ & $7.31 \%$ \\
\hline & A positive feeling & & 103 & $13.48 \%$ & $2.68 \%$ \\
\hline & $\begin{array}{l}\text { A political or ethical } \\
\text { opinion }\end{array}$ & & 26 & $3.40 \%$ & $0.68 \%$ \\
\hline COMMUNITY & $\begin{array}{l}\text { Place of psychological } \\
\text { support }\end{array}$ & & 103 & $35.40 \%$ & $2.68 \%$ \\
\hline & $\begin{array}{l}\text { Place to exchange ideas, } \\
\text { meet similar people }\end{array}$ & & 86 & $29.55 \%$ & $2.24 \%$ \\
\hline & $\begin{array}{l}\text { Dare to tackle a taboo, } \\
\text { embarrassing subject }\end{array}$ & & 42 & $14.43 \%$ & $1.09 \%$ \\
\hline & $\begin{array}{l}\text { Business purposing, } \\
\text { Advertising }\end{array}$ & & 32 & $11.00 \%$ & $0.83 \%$ \\
\hline & $\begin{array}{l}\text { Participatory experience, } \\
\text { community survey, } \\
\text { knowledge aggregation }\end{array}$ & & 28 & $9.62 \%$ & $0.73 \%$ \\
\hline
\end{tabular}

This category includes messages that are posted in order to tell one's story, one's experience, or often convey polarized feelings (negative though a catharsis, or positive when sharing good news, an improvement). 
Catharsis is strongly represented, people come to this forum to express (in order of frequency): moral suffering/sense of despair, sense of deadlock/diagnostic dead-end, feeling misunderstood, physical suffering/pain, sense of disability, feeling guilty, anger, complex, emotional trauma, conveying bad news.

The desire to testify is a strong motivatior as people relate their experiences, which often corresponds to their personal history, the history of the disease, their experience, an acquaintance, an advice, an expertise, a confidence, alerting the community of a danger.

Positive feelings are a minority : "I used to drink like a fish, I managed to stop in one week, through sheer willpower,[...]»

\section{Community (Fig 5)}

Some participants post messages in a community spirit, so as to create links with other members, to obtain the support of a group, even anonymously. The most important factor seems to be psychological support "[...] On this forum I am just looking for moral support [...]» and the desire to develop intimate links through the internet «Maybe I could meet people in the same situation as me, it could be reassuring or maybe depressing.»

\section{Meeting a health professional (Fig 6)}

The mention of a health professional is coded 651 times (592 posts on the forum). In $80.9 \%$ messages, users have already consulted a doctor. The rest either plan to consult, don't want to, are unable to because of doctor's unavailablity, or ask if it is necessary.

The proportion of messages mentioning that they have already consulted a caregiver before posting a message is less than $1 / 3$ of the corpus $(30.23 \%, 479$ posts, 496 codes).

The distribution of codes for users who have already consulted a doctor is as follows:

Among those who explicitly state that they have already consulted a health professional, $70.98 \%$ (340 posts) request further medical information. $65.97 \%$ (316 posts) express a need for additional reassurance, despite the consultation : "I went to see a doctor [...] He [...] prescribed Lyrica which I have not yet taken because I have the impression that it is quite a strong drug. Despite the fact that he told me that it was nothing serious, I am very stressed, frightened, [...]”

However, there are 472 posts with a view to obtain reassurance, when the user does not say that they have consulted a health professional (59.89\% of the posts expressing worry).

Of the 1584 analyzed verbatims, only 190 (about 12\%) explicitly refer to their GP.

About $59.5 \%$ of the messages do not explicitly mention a relationship with a health care provider in their post, so it seems that they consider solving their problem via the health forum or talking about their situation to the forum community first. 


\section{Possible barriers to consultation experienced by patients}

Not having consulted previously can be explained by the immediate unavailability of the doctor (temporal or geographical), (3.41\% of analyzed posts). On the forum, there are neither spatial, nor temporal barriers which allows the user to ask their question immediately, without having to go anywhere. «here I am, waiting for my appointment with my doctor. "

Categorical refusal to consult is rare (1.64\% of the total corpus). Fear or shame of consulting constitute the majority of the refusals.

The notion of community is central, it is possible to talk anonymously to a group. This is the main motivation for about 7,57\% of the corpus: "I wanted to open this discussion because we need to share our experience [...]. I want to share our journey to try for a baby that ended up positively or negatively [...], we need others to share... " The forum is used as a space of psychological support, of exchanges between fellow human beings which allows to create interpersonal links via the Internet, or to approach a taboo subject online because of its embarrassing character: "I know it's abnormal but I don't dare go to my doctor, $[. .\} .$.

\section{Discussion}

\section{Main Findings}

The findings suggest that the main motivations of the users of an online forum are the search for medical information, the request for feedback in order to have the testimony of someone who has experienced the same situation, and the need for reassurance in several domains.

The people who participate in this health forum seem to mainky want to find an answer to a medical question, asked anonymously, immediately, within a group. Organisation is more convenient and a quick answer without waiting for an appointment with one's doctor is easily obtained.

The search for feedback is very interesting, because this notion does not exist during a medical consultation, how patients feel and testify is what remains important.

The need for reassurance is also represented, it echoes a concern expressed by the person who posts. This anxiety can be caused by different everyday phenomena. In most cases, it is induced by the appearance of symptoms (a physically visible sign, a felt functional sign, a pain).

The main purposes that emerge from this work seem to be modelled on the functioning of human-tohuman communication. Messages can be used to communicate an emotion or an attitude, to transmit information or to refer to the context, to play with language, to establish a contact with the other, to use language to try to make the recipient (re)act. ${ }^{18}$ 
On this forum, negative affects are over-represented. Indeed, the people who come to share are generally doing it to free themselves from these emotions. Sharing their affects and their mostly negative experiences allows them to obtain social support from the community. ${ }^{18}$

The formulation of their concerns also makes it possible to obtain support, associated with a reassurance.

The relationships with a health professional reported in our study are often conflicting or express a lack of confidence in the opinion of the medical interlocutor. These doubts seem to be largely explained by a lack of information, and the participants decide to obtain confirmation of the medical opinion on the forum. The therapeutic value of a quality doctor-patient relationship is priceless. ${ }^{19}$ The need for clear information, helping them to understand their health problem, seems to be a central concern. ${ }^{20}$

\section{Comparison with other studies}

Battaia's work (2012) on health discussion forums supports the external consistency of our study. Pure medical information is at the center of concerns ${ }^{21}$ expressed on health forums ; moreover, patients seem to be looking for disease-related life stories ${ }^{21}$ which triggers emotions. These do not come into play in the exchange of medical information but only in the exchange of testimonies and feelings about the disease. ${ }^{21}$ Rather than the legitimacy of the professionals it is the experience of living with the disease that is valued. ${ }^{11}$ And yet, the study shows that medical information is a central element of the Internet users' stories, and participants need to deepen their knowledge while being reassured. ${ }^{11}$

\section{Strengths and limitations}

This study is original. Non-directive, it uses data from a health forum, where expression is free, avoiding a bias in data collection. The use of double coding allows to reduce the bias of subjectivity. ${ }^{22}$

A qualitative analysis based on the grounded theory approach ${ }^{16,17,23}$ is particularly adapted to this work, ${ }^{24}$ since the factors we observe are feelings, intentions, emotions, reactions. The use of a mixed method combining qualitative and quantitative analysis allows to enrich the understanding of the studied phenomenon. 22,24

Here, we used raw data from an online health forum, which is a credible source in the field of qualitative research. ${ }^{9}$ The analysis made it possible to inductively generate a theorization of the phenomenon of these forums by proceeding through conceptualization, thus progressively linking qualitative data. ${ }^{16}$

All these elements strengthen the internal validity of our study.

However, this work has some limitations. The descriptive and retrospective nature of the study lowers the level of evidence. The representativeness of our sample is difficult to establish since only active users have a voice and because of the anonymity of the participants, even if a few communicate information 
about themselves. It also appears that the audience of this forum is largely female. ${ }^{25}$ The forum is strictly French-speaking and therefore accessible only to people who understand the language. This may weaken the external validity of the study.

Silent readers who do not post a first message or participants who have written following a thread are not taken into account in the study, which may create a lack of data. Nevertheless the theoretical saturation of the data was reached after having read 1584 posts entered in the analysis.

\section{Conclusion}

The importance of the internet and social networks in our lives is undeniable, and medical practice is no exception. Understanding what patients are looking for and finding online is essential for the modern doctor. This study aims to analyze the verbatims posted by the general public on a French medical forum in order to identify what the participants are looking for.

This study highlights the fact that beyond the research of medical information that does require a health care provider's technical knowledge, patients come to confront their feelings, worries and emotions within a community in which they feel free and legitimate. Resorting to the information found on the Internet is a means to reassure themselves, to confirm their hypothesis or the one provided by a health professional.

Another practical advantage of these forums is getting an immediate response which could also be offered by the development of teleconsultation in France.

It is necessary to integrate this new source of (online) information available to all, in order to increase the patient's trust and adherence to a fair and reasoned model of care.

The patient-doctor relationship should be based on appropriate communication. This communication, if well conducted, should allow for a better analysis of the patient's expectations, whether they are clearly visible or hidden. In this way, emotional needs can be better met and the patient's feelings can be soothed. Creating a space of trust in which the patient feels free to confide is also a challenge in primary care.

A further quantitative statistical analysis of the database should be led so as to specifically examine the links between 'mentioning a doctor' (before or after a consultation) and the patient's motivations, and then compare the results with the interactions among forum participants who do not mention a doctor.

\section{Abbreviations}

GP

General Practitionner

\section{Declarations}




\section{Ethics approval and consent to participate}

The data used are from an online health forum are anonymised and freely available. We obtain oral and written consent from the managers of the 'Doctissimo' forum. All methods were carried out in accordance with relevant guidelines and regulations.

\section{Consent for publication}

Not applicable.

Availabilty of data and materials

The data used are publicly available and dataset used and analysed during the current study are available from the corresponding author on reasonable request.

\section{Competing interests}

The authors declare that they have no competing interests.

\section{Funding}

There was no funding for this study.

\section{Authors' contributions}

YMV and PD were in charge of the methodology part, while ALB and VM were the two researchers conducting the qualitative and quantitative analyses. All authors participated in drafting the manuscript. The author(s) read and approved the final manuscript.

\section{Acknowledgments}

We would like to thank Jonathan Montané for his computer skills and Rebecca Dahm for her writing assistance.

\section{Author information}

Affiliations

1. Département de Médecine Générale, Université de Bordeaux, Collège Sciences de la santé, 146 rue Léo Saignat, 33076, Bordeaux Cedex, France

Ambre-Laure Benazeth, Valentin Montané, Christophe Adam, Christèle Blanc-Bisson, Palina Dzeraviashka \& Yves-Marie Vincent

\section{References}


1. Gay B. Repenser la place des soins de santé primaires en France - Le rôle de la médecine générale. Rev DÉpidémiologie Santé Publique. 2013;61(3):193-198. doi:10.1016/j.respe.2013.01.095

2. Balint M. THE DOCTOR, HIS PATIENT, AND THE ILLNESS. The Lancet. 1955;265(6866):683-688. doi:10.1016/S0140-6736(55)91061-8

3. Lewis J. Patient views on quality care in general practice: Literature review. Soc Sci Med. 1994;39(5):655-670. doi:10.1016/0277-9536(94)90022-1

4. Williams S, Weinman J, Dale J, Newman S. Patient expectations: what do primary care patients want from the GP and how far does meeting expectations affect patient satisfaction? Fam Pract. 1995;12(2):193-201. doi:10.1093/fampra/12.2.193

5. Ruiz-Moral R, Torres L, Jaramillo-Martin I. The Effect of Patients' Met Expectations on Consultation Outcomes. A Study with Family Medicine Residents. J Gen Intern Med. 2007;22(1):86-91. doi:10.1007/s11606-007-0113-8

6. Little P, Everitt H, Williamson I, et al. Observational study of effect of patient centredness and positive approach on outcomes of general practice consultations. BMJ. 2001;323(7318):908-911. doi:10.1136/bmj.323.7318.908

7. Mrouki M, Jridi M, Hamrouni S, Cherif Y, Ben Dahmen F, Abdallah M. Internet mobile dans la pratique courante. Rev Médecine Interne. 2019;40:A101. doi:10.1016/j.revmed.2019.03.092

8. Eysenbach G, Powell J, Kuss O, Sa E-R. Empirical studies assessing the quality of health information for consumers on the world wide web: a systematic review. JAMA. 2002;287(20):2691-2700. doi:10.1001/jama.287.20.2691

9. Im E-O, Chee W. An Online Forum As a Qualitative Research Method: Practical Issues. Nurs Res. 2006;55(4):267-273. doi:10.1097/00006199-200607000-00007

10. Seale C, Charteris-Black J, MacFarlane A, McPherson A. Interviews and Internet Forums: A Comparison of Two Sources of Qualitative Data. Qual Health Res. 2010;20(5):595-606. doi:10.1177/1049732309354094

11. Battaïa C. Information médicale et émotion dans les forums de santé. Cah Numer. 2016;12(1):5172.

12. Mediametrie. Audience Internet Global en France en janvier 2020. Published March 2020. Accessed June 4, 2020. https://www.mediametrie.fr/sites/default/files/2020-03/2020\%2003\%2004\%20\%20CP\%20Audience\%20Internet\%20Global_Janvier\%202020\%20vdef_0.pdf

13. Wu B, Jiang S, Chen $\mathrm{H}$. Effects of Individuals' Motivations on Communications in Online Health Forums. Soc Behav Personal Int J. 2016;44(2):299-312. doi:10.2224/sbp.2016.44.2.299

14. Bell RA, Hu X, Orrange SE, Kravitz RL. Lingering questions and doubts: Online information-seeking of support forum members following their medical visits. Patient Educ Couns. 2011;85(3):525-528. doi:10.1016/j.pec.2011.01.015

15. Sokolova M, Bobicev V. What sentiments can be found in medical forums? Int Conf Recent Adv Nat Lang Process RANLP. Published online January 1, 2013:633-639. 
16. Paillé P. L'analyse par théorisation ancrée. Cah Rech Sociol. 1994;(23):147-181. doi:https://doi.org/10.7202/1002253ar

17. Lejeune C. Manuel d'analyse Qualitative. Analyser sans Compter Ni Classer. DeBoeck Supérieur.; 2019.

18. Lombart E, Fairon C. Spécificités de communication des forums de discussion. Corpus. 2020;(21). doi:10.4000/corpus. 5356

19. Parker D, Byng R, Dickens C, Kinsey D, McCabe R. Barriers and facilitators to GP-patient communication about emotional concerns in UK primary care: a systematic review. Fam Pract. 2020;37(4):434-444. doi:10.1093/fampra/cmaa002

20. Prescrire Redaction. Les patients veulent savoir. Rev Prescrire. 2011;31(338):937.

21. Battaïa C. L'analyse de l'émotion dans les forums de santé (Analysis of Emotion in Health Fora). ATALA/AFCP. 2012;3:267-280.

22. Kohn L, Christiaens W. Les méthodes de recherches qualitatives dans la recherche en soins de santé: apports et croyances. Reflets Perspect Vie Econ. 2014;Tome LIII(4):67-82.

23. Méliani V. Choisir l'analyse par théorisation ancrée: illustration des apports et des limites de la méthode. Rech Qual. 2013;15:435-452.

24. Aubin-Auger I, Mercier A, Baumann L, Lehr-Drylewicz A-M, Imbert P. Introduction à la recherche qualitative. Exercer. 2008;84:142-145.

25. Touboul A, Vercher $E$. Communication et santé: entre rationalité marchande, logique d'information et communauté d'intérêts. tic\&société. 2008;2(1). doi:10.4000/ticetsociete.378

\section{Figures}


Fig 1. Users' motivations on the 'Doctissimo' health forum

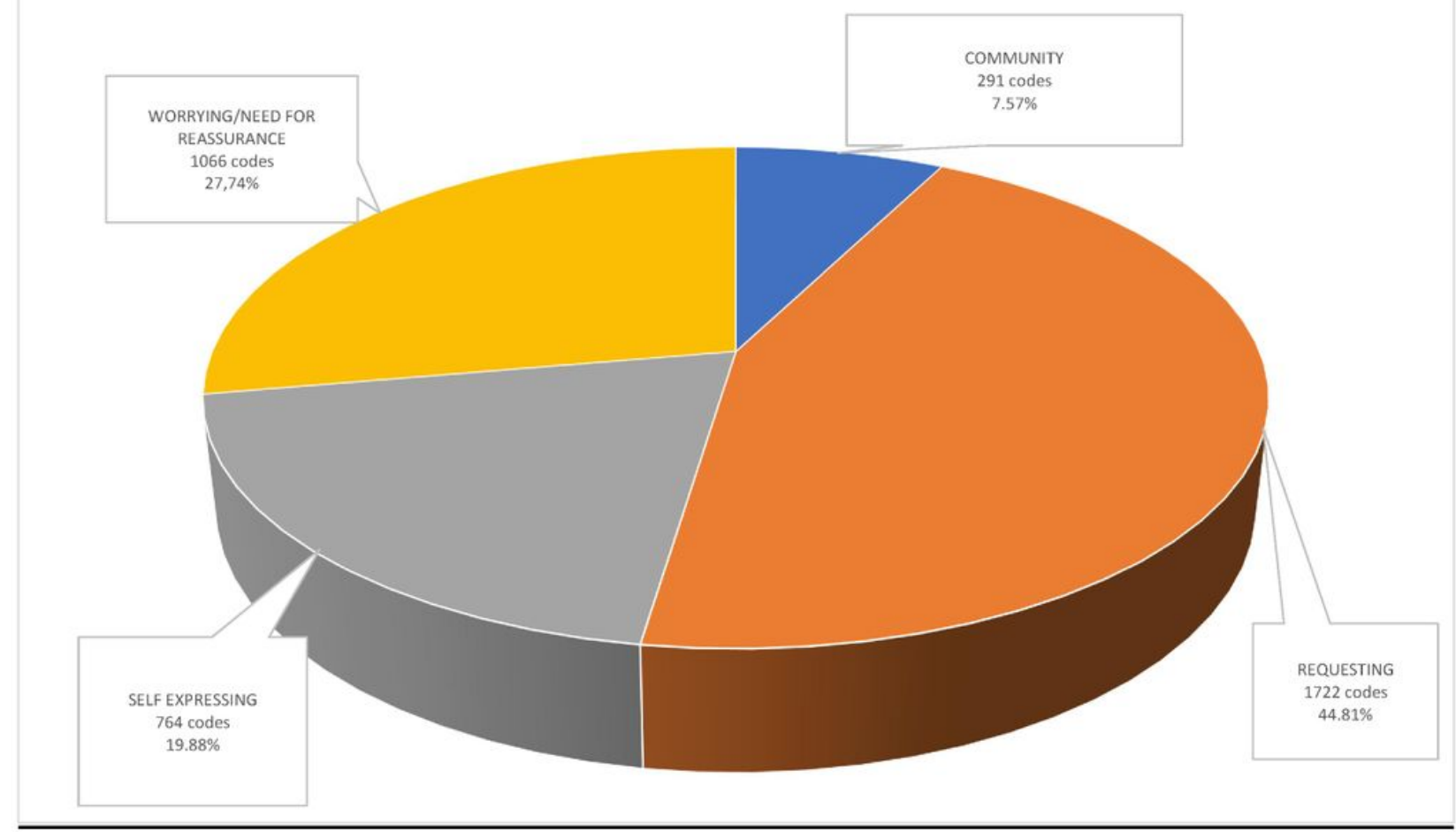

Figure 1

Users' motivations on the 'Doctissimo' health forum 
Fig 2. Category 'REQUESTING'

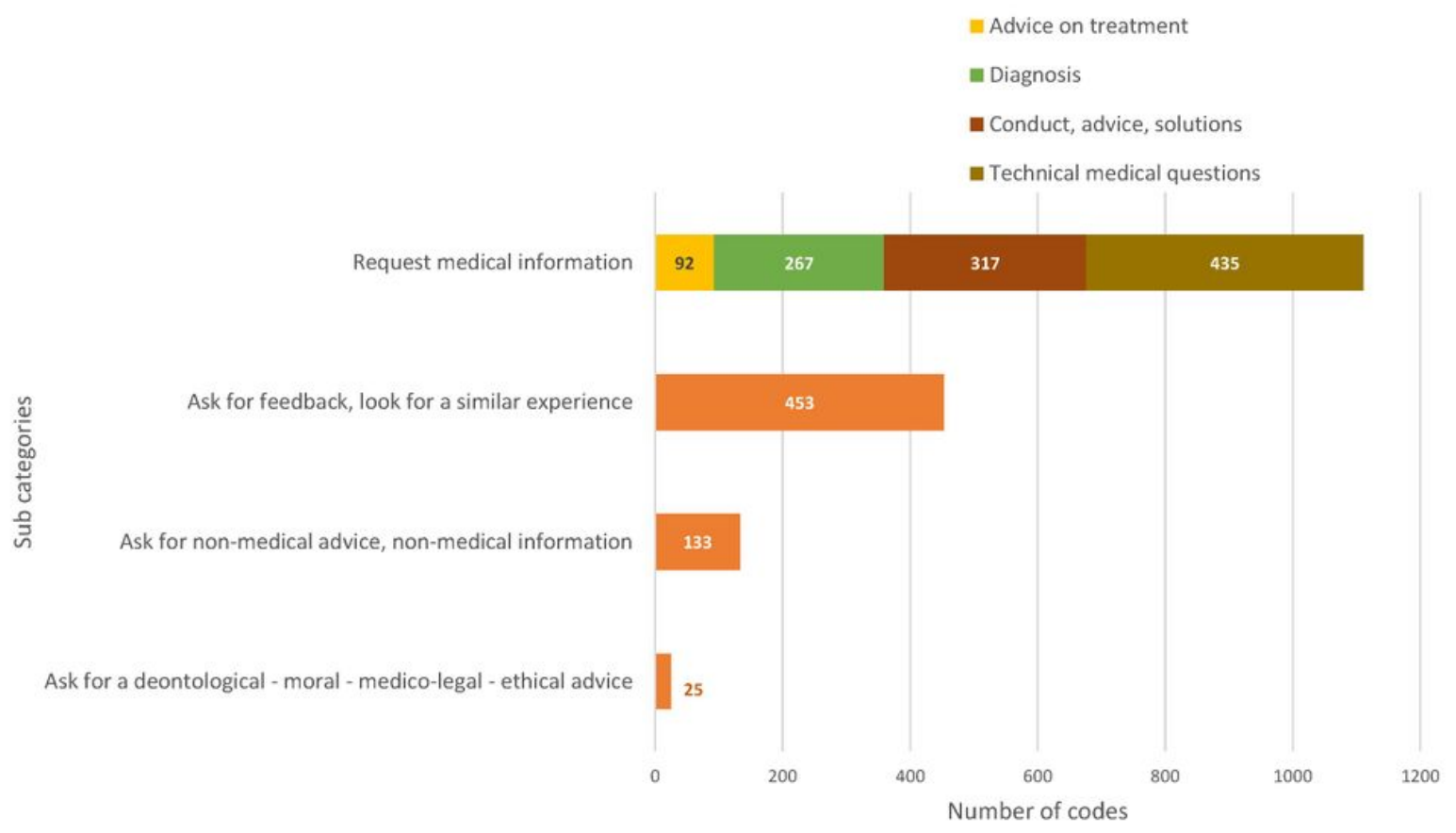

Figure 2

Category 'REQUESTING' 
Fig 3. Category 'WORRYING/NEED FOR REASURANCE'

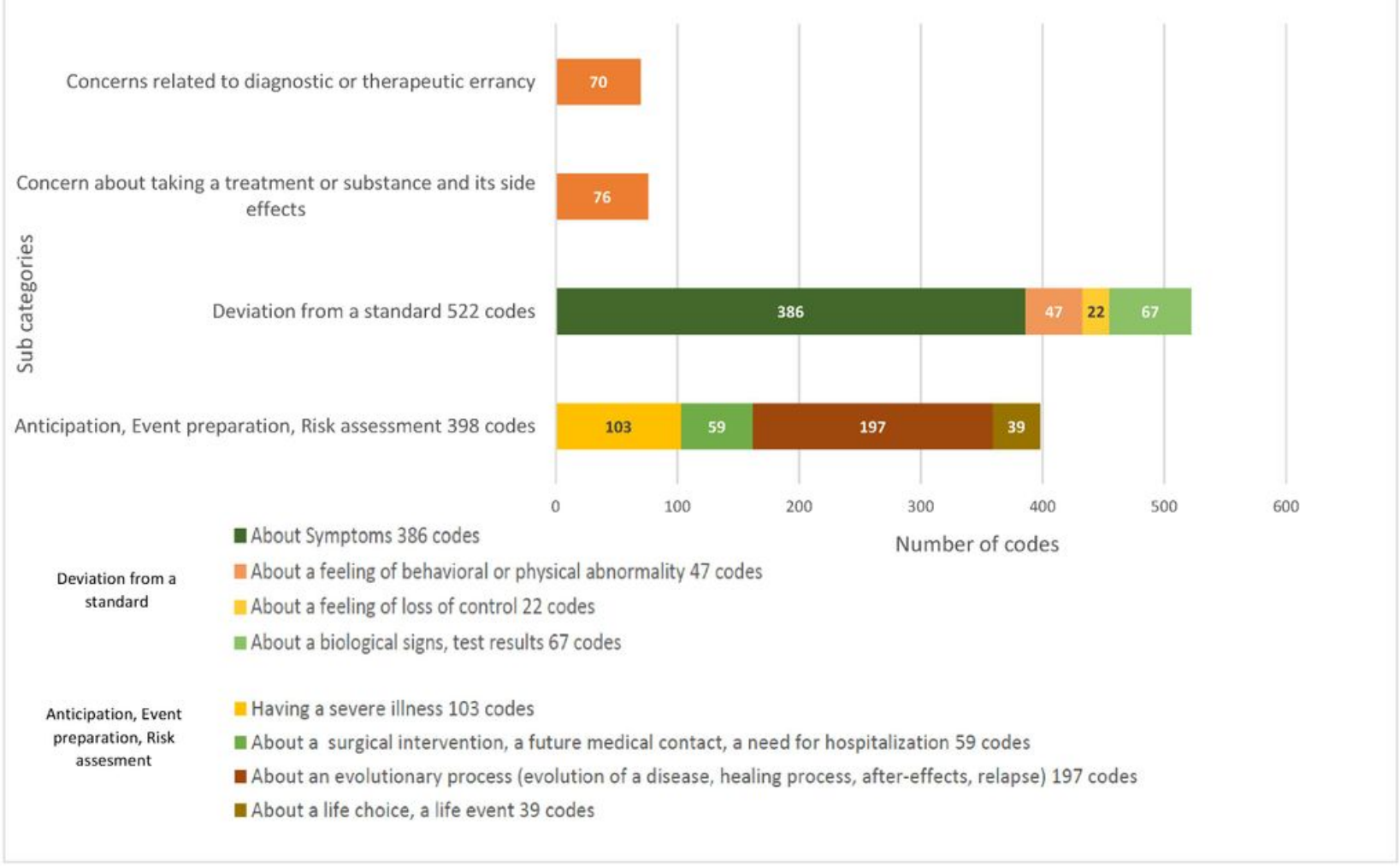

Figure 3

Category 'WORRYING/NEED FOR REASURANCE' 


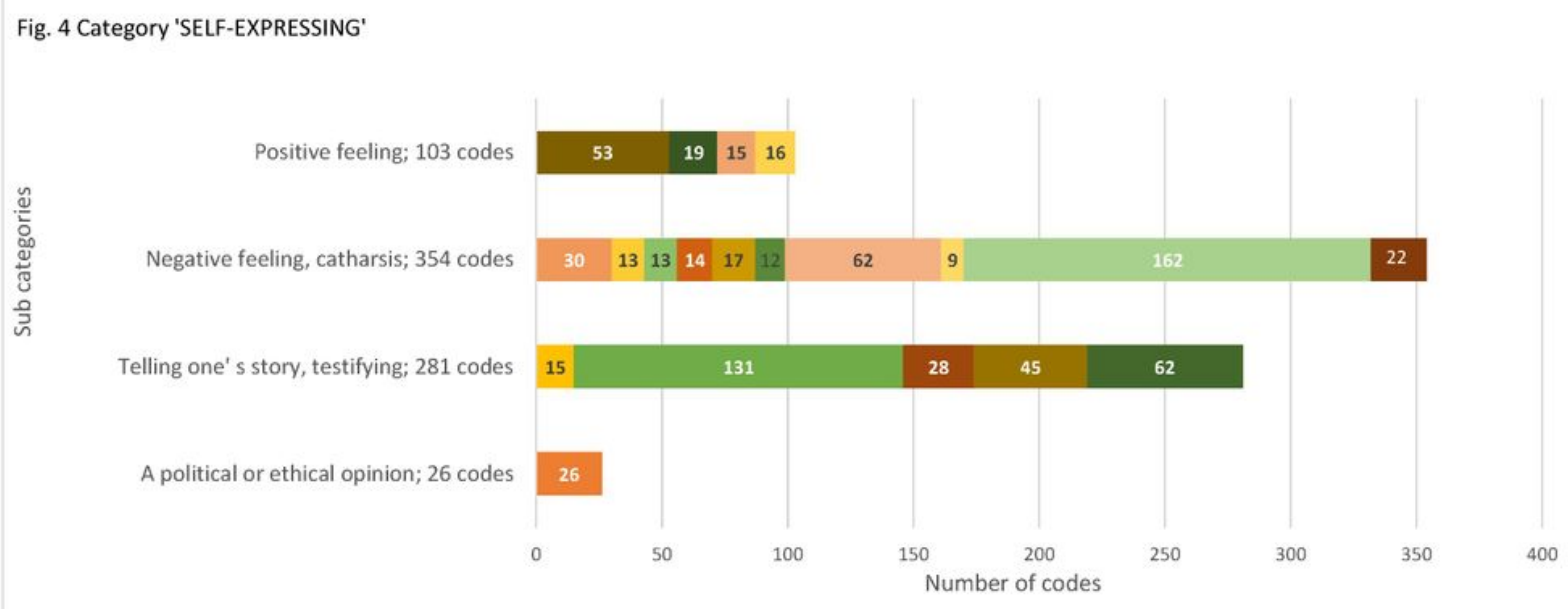

\section{Positive feeling}

- Helping the community; 53 codes

- Improvement, healing; 19 codes

Resolution, decision; 15 codes

Negative feeling, catharsis

Recommendations for treatment; 16 codes

= Feeling of being misunderstood; 30 codes

anger; 13 codes

= Complex; 13 codes

Telling one's story, testifying

Alerting the community to danger; 15 codes

- Feeling of guilt; 14 codes

= Feeling of handicap; 17 codes

Emotional trauma; 12 codes

Personal history, history of one' s illness; 131 codes

- Feeling of deadlock/diagnostic impasse; 62 codes

Bad news; 9posts

" Moral suffering/feeling of despair; 162 codes

Knowledge, advice, expertise; 45 codes

Experience; 62 codes

- Physical suffering/pain; 22 codes

\section{Figure 4}

\section{Category 'SELF-EXPRESSING'}




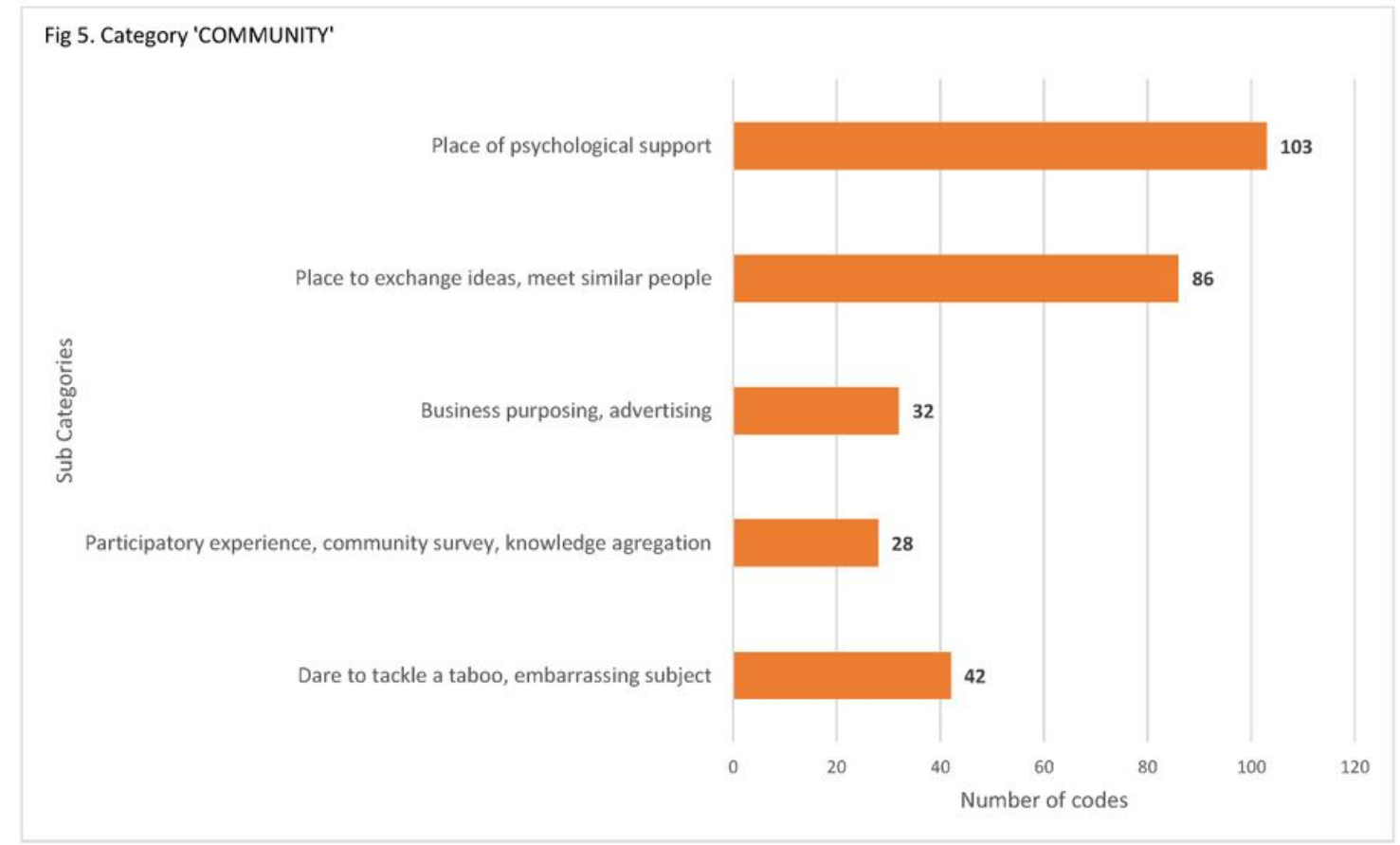

\section{Figure 5}

Category 'COMMUNITY' 


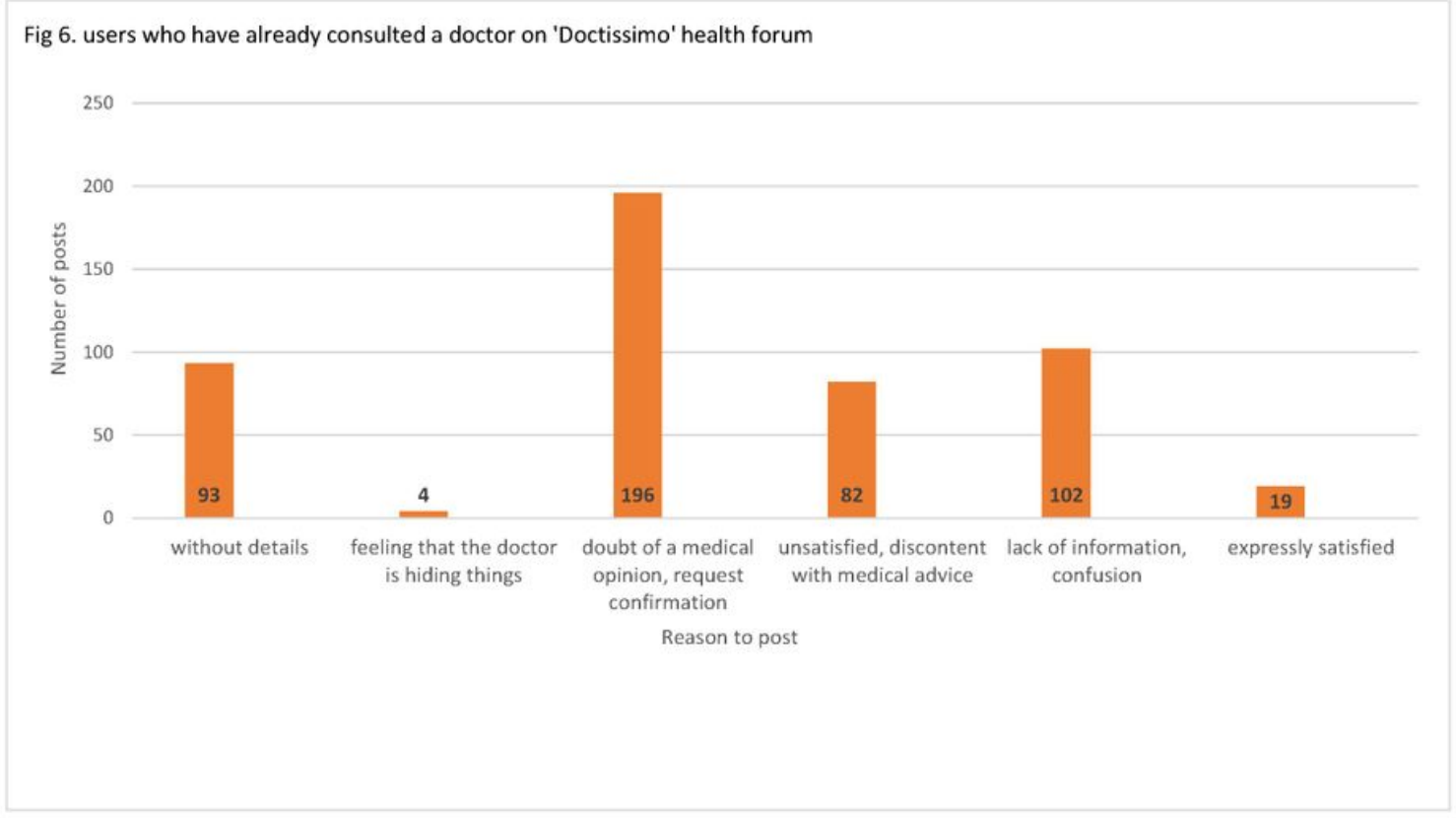

\section{Figure 6}

users who have already consulted a doctor on 'Doctissimo' health forum 